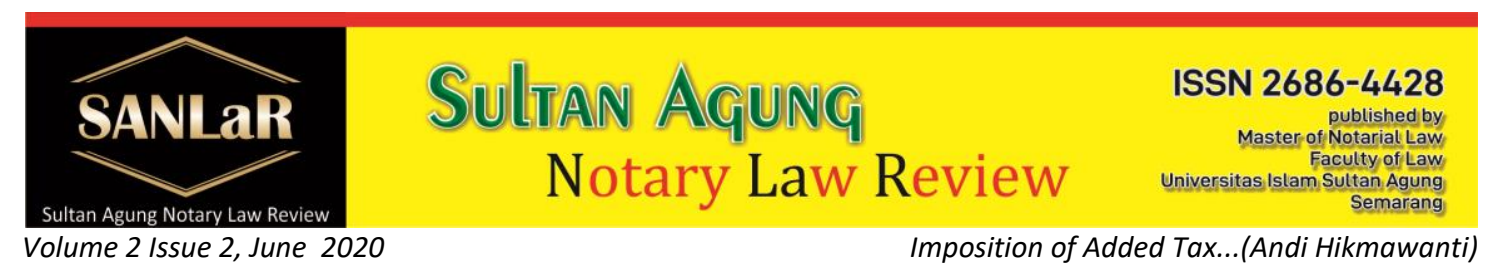

\title{
Imposition of Added Tax Value on Notary Services/PPAT
}

\author{
Andi Hikmawanti ${ }^{*}$, Amin Purnawan ${ }^{* *}$ \\ *) Students of Master of Notary Law, Universitas Islam Sultan Agung (UNISSULA) \\ Semarang, E-Mail: unissula.hikmawantiandi@gmail.com \\ ${ }^{* *}$ ) Lecturer of Master of Notary Law, Universitas Islam Sultan Agung (UNISSULA) \\ Semarang
}

Abstract. With the imposition of Added Tax Value (ATV) on notary/PPAT services, it is necessary to know the implementation of the imposition of Added Tax Value on Notaries/PPAT based on the Added Tax Value law and what problems and solutions are faced in charging ATV for such notary/PPAT services. This research is descriptive analytical with an empirical juridical approach with the research location in the Kendari City area. Based on the research results, it was found that the Notary/PPAT in Kendari City has not been registered as a Taxable Entrepreneur in Kendari City. This is due to several reasons, namely the tax office still has difficulty calculating the value of the deed made by the Notary/PPAT in Kendari City because no reporting. Another problem that hinders the collection of ATV for Notaries/PPATs is the demand for collection wages as the government gives incentives to agencies that collect taxes so that they are willing to establish themselves as taxable entrepreneurs.

Keywords: Tax; Value; Notary; PPA.

\section{Introduction}

In the 2019 State Budget, taxes are still the largest source of state revenue. Because tax is a form of state income that contributes the largest percentage compared to other income sectors such as oil and gas (oil and gas) and non-oil and gas. Taxes and other levies that are compelling in the interests of the state are regulated by law, so that only the state can impose taxes and is certain for the needs of the state, in accordance with its essence, taxes are of a coercive nature. ${ }^{1}$ In the 2019 State Budget, the state revenue is IDR 2,165 trillion of $82.5 \%$ or IDR 1,784 trillion is tax revenue, while PNBP is $17.5 \%$ and grants are $0.4 \% .^{2}$ The better the community's participation in paying taxes, the more benefits that will be enjoyed, such as cheaper education costs, better and cheaper public facilities and all social facilities as well as adequate security for all citizens. ${ }^{3}$

One of the sources of state revenue in the tax sector is Added Tax Value for Notary Services and PPAT. Added Tax Value, which consists of goods and services and sales tax on luxury goods. In this case regarding Service ATV, Added Tax Value (ATV) was first

\footnotetext{
${ }^{1}$ Wirawan, B. Ilyas and Richad Buston. (2013). Hukum Pajak. Jakarta: Bina Kata.p.5

${ }^{2}$ https://www.pajak.go.id/id/artikel/kemandiran-yang-menginspirasi, accessed on 16 October 2019

3 Judisenno, Rimsky K. (2002). Pajak Dan Strategi Bisnis (Suatu Tinjauan Tentang Kepastian Hukum Dan Penerapan Akuntansi Di Indonesia. Jakarta: Gramedia Pustaka Umum. p.35
} 
introduced by Carl Friedrich von Siemens, an industrialist and consultant to the German government in 1919. However, ironically, the French government applied ATV for the first time in the taxation system at the beginning of 1954, while Germany just implemented it in early 1968. Indonesia just adopted on April 1, 1985, replacing Sales Tax (PPn) which had been in effect in Indonesia since $1951 .{ }^{4}$

Based on Article 4 letter c of Act No. 42 of 2009 concerning the third amendment to Act No. 8 of 1983 concerning Added Tax Value for goods and services and sales tax on luxury goods, ATV is imposed on the delivery of Taxable services performed by entrepreneurs. Because these entrepreneurs provide taxable services, and based on Article 1 point 15 these entrepreneurs are taxable entrepreneurs. Furthermore, based on Article 1 point 14, an individual or entity that delivers Taxable services can be classified as an entrepreneur if the activity is carried out in business activities or work. In accordance with these provisions, the Notary/PPAT in his services is subject to a rate of $10 \%$.

\section{Research Methods}

The approach method used in this research is descriptive analytical, namely using juridical empirical, juridical, namely taking inventory and analyzing the laws and regulations relevant to the object of research, in this case the provisions related to the imposition of ATV for Notaries and PPAT while empirical is to examine the implementation of ATV imposition for Notaries and PPAT especially in Kendari City. Primary data from this research obtained through direct interviews with interested parties, in this case Notary or PPAT of Kendari city, tax consultants and Kendari Pratama Tax office. Secondary data through library research by searching official documents, books related to the object of research, research results in the form of reports, theses, dissertations and statutory regulations.

\section{Results and Discussion}

3.1. Implementation of Charging Added Tax Value (ATV) on Notary Services/Land Deed Making Official (PPAT) Based on the Added Tax Value Law

Notary is a/Land Deed Making Official (PPAT) is a public official who is authorized by the government to make authentic deeds. Charges for services provided by a Notary Public/PPAT in the Value Added Law can be seen from the object and subject of Value Added. The main task of the Notary is to make an authentic deed. As for the word authentic, based on Article 1870 of the Civil Code, it provides the parties that make it a perfect proof. Herein lies the important meaning of a Notary, that a Notary, because the law is given the authority to create a perfect means of proof, in the sense that

\footnotetext{
${ }^{4}$ Sukardji, Untung. (2015). Pokok-pokok Pajak Pertambahan Nilai Indonesia edisi revisi 2015. Jakarta: Raja Grafindo. p.1
} 
what is stated in the authentic deed is basically considered true as long as there is no evidence to the contrary. ${ }^{5}$

Meanwhile, PPAT is the official authorized to make authentic deeds of transfer of land rights, appointed and dismissed by the minister who is responsible for agrarian/land affairs. All matters relating to the duties and authorities of PPAT are affirmed in Government Regulation Number 37 of 1998 concerning the Position Regulations for Making Land Deeds as outlined on March 5, 1998 (State Gazette of 1998 Number 52, Supplement to the State Gazette Number 3746). PPAT has an important and strategic task in the implementation of land registration, namely making deeds of transfer of land rights. Without evidence in the form of a PPAT deed, the Heads of the Land Office are prohibited from registering the legal acts concerned ${ }^{6}$.

Services provided by Notaries and PPAT may be subject to Added Tax Value (ATV). This is confirmed in Article 1 paragraph (7) of the Decree of the Director General of Taxes Number. KEP-05/PJ/1994 which has stated that legal services are included as taxable services, while what is meant by legal services according to this regulation are:
a. Lawyer Services;
b. Notary Services/PPAT;
c. Legal Aid Institution Services;
d. Tax Consultant Services;
e. Other Legal Services.

With this regulation, it is clear that the intention of the government is to classify Notary/PPAT whose position as a public official who has the authority to make authentic deeds for the benefit of the public in general is a Added Tax Valueable service.

The law classifies Notaries as Taxable Entrepreneurs, so that Notaries/Land Deed Making Officials (PPAT) who are not classified as Small Entrepreneurs according to the Minister of Finance are required to report their business activities to be confirmed as Taxable Entrepreneurs, so that the services they provide are subject to Tax. Value Added

Notaries as public officials in carrying out their duties make authentic deeds at the request of the general public which according to the law on value added are taxable

\footnotetext{
${ }^{5}$ Dr. Ngadino. Sh. Sp.N. MH. (2019). Tugas Dan Tanggung Jawab Jabatan Notaris Di Indonesia. Semarang: Univ. PGRI Semarang Press. p. 8 ${ }^{6}$ Dr. Ngadino. SH. Sp.N. MH. (2019). Ketentuan Umum Tata Cara Pembuatan dan Pengisian Akta PPAT. Semarang: Univ. PGRI Semarang Press. p. 22
} 
services payable, so that in delivering services, they must be confirmed as taxable entrepreneurs if the gross turnover in 1 year exceeds IDR 4,8 billion .

In accordance with Article 2 paragraph 1 Regulation of the Minister of Finance Number 197/PMK.03/2013 regulates that: "Small entrepreneurs are entrepreneurs who for 1 (one) financial year deliver taxable goods and/or taxable services with a gross turnover and/or gross revenue and/or gross revenue of not more than IDR 4,800,000,000, (four billion eight hundred million rupiah)".

Furthermore, Article 4 paragraph 1 regulates that "Entrepreneurs are required to report their business to be confirmed as a Taxable Entrepreneur, if up to one month in the financial year the gross turnover and/or gross revenue exceeds IDR4,800,000,000.00 (four billion eight hundred million rupiah)".

Notary/Land Deed Making Official (PPAT) whose income exceeds IDR 4,800,000,000.00 (four billion eight hundred million rupiah) in one year, must be confirmed as a Taxable Entrepreneur. Notary/Land Deed Making Official (PPAT) who is classified as a Small Entrepreneur does not need to report his business activities to be confirmed as a Taxable Entrepreneur. Notary/Land Deed Making Official (PPAT) who is registered as a Taxable Entrepreneur is obliged to collect Added Tax Value continuously for every service it provides.

Notary/Land Deed Making Official (PPAT) can choose to be confirmed as a Taxable Entrepreneur. This may occur because the Notary/Land Deed Making Officer (PPAT) has a colleague and wants to charge Added Tax Value for his services.

Before being confirmed as a taxable entrepreneur, Notary/PPAT must be registered as a taxpayer and have an NPWP, then registered as PKP. in line with the development of information technology of the director general of tax in order to improve services to taxpayers and/or taxable entrepreneurs to register themselves and/or report their business activities through an online-based information system network according to the Director General of Taxes Regulation Number Per-02/Pj/2018 Regarding the Second Amendment to the Regulation of the Director General of Taxes Number Per20/Pj/2013 concerning Procedures for Registration and Issuance of Taxpayer Identification Numbers, Business Reporting and Confirmation of Taxable Entrepreneurs, Abolition of Taxpayer Identification Numbers and Revocation of Taxable Entrepreneurs Confirmation, and Data Changes And Transfer of Taxpayers.

According to Arum, $\mathrm{SE}^{7}$, the Added Tax Value Consultation section of the Kendari Pratama Tax Office confirmed that a Notary/PPAT who can collect ATV is a Notary Who has been confirmed as a taxable entrepreneur. One of the Notaries in Kendari Rima Anggraini, SH.MKn ${ }^{8}$ also conveyed that Notaries/PPATs who are not PKP do not collect ATV on their clients.

\footnotetext{
${ }^{7}$ Interview with Arum, SE., Kendari Pratama Tax Officer on 12 January 2020

8 Interview with Rima Anggraini, SH.MKn., Notaries in Kendari 12 January 2020
} 
Notary/PPAT as a taxable entrepreneur will notify his client that every deed making transaction using the services of a Notary will be subject to Added Tax Value of $10 \%$ of the transaction value of the deed he has made. If the client agrees and has met the requirements related to making a deed, then a deed is made, then the notary will fill in the ATV tax invoice which is evidence that tax collection made by the Notary/PPAT as an Entrepreneur is subject to ATV tax.

Every month, the Notary/PPAT must also fill in ATV Period Notification Letter based on how much he issues the tax invoice or the provision of his services to his clients who come to him. Then the ATV Periodic Tax Return will be reported by a Notary to the Tax Service Office (KPP) where he is registered as a Taxable Entrepreneur. This ATV Periodic Tax Return is given by the Tax Service Office to Notary/PPAT who is registered as a Taxable Entrepreneur at the Kendari Tax Office. This report is submitted no later than the 20th of each month to the Tax Office with an online deposit point or to the tax office. After this reporting, the tax officer will examine the accuracy of the report.

3.2. Constraints and solutions in the Implementation of Added Tax Value (ATV) on Notary Services/Land Deed Making Official (PPAT) Based on the Added Tax Value Law

Problems in implementing ATV collection for Notary/PPAT Services according to Muh. Tahir SE (Tax Consultant), explain that there are several Notaries in Kendari City who have the potential for PKP but the tax office has difficulty getting reports from Notaries/PPAT because there is no value or work contract on the deed they make. For example, making a sale and purchase deed, there is no written agreement between the Notary and the client regarding the amount of honor or fee to be received because each region differs in the price of the Sale Deed even though the fee from AJB is $1 \%$ of the transaction price stated in the deed and then in There is also another tax deed of sale and purchase, namely PNBP (Non-Tax State Revenue) so that if you are subject to ATV again, it will give the impression that it is a repetitive tax that makes the client object.

The same thing was stated by Lutfi. ${ }^{9}$ The Taxpayer Supervision Section of the Kendari Pratama Tax Office stated that in the city of Kendari, Southeast Sulawesi, there are no notaries who have become taxable entrepreneurs. This fact shows that the state has lost a source of state revenue from the PPN revenue sector from Notary/PPAT services. The potential for this state revenue should be maximized for the benefit of national development. Therefore, it is necessary to further regulate the importance of recording transactions for Notary Services and PPAT and reporting the data regularly to the Primary Tax Office so that it can be confirmed as a Taxable Entrepreneur (PKP).

\footnotetext{
${ }^{9}$ Interview with Lutfi, Notary in Kendari, on 14 January, 2020
} 
According to Notary Arung Widya, SH.MKn ${ }^{10}$ (Notary in Kendari) states that if a Notary/PPAT is given the authority to collect ATV, there should be a collection fee for the Notary/PPAT just like that given to government agencies that collect taxes.

As in Article 171 paragraph 1, 2.3 of the Law of the Republic of Indonesia Number 28 of 2009 concerning Regional Taxes and Regional Levies, which reads as follows:

a. Agencies that collect taxes and levies can be given intensively on the basis of achieving certain performance

b. The incentives as referred to in paragraph (1) shall be determined through the Regional Revenue and Expenditure Budget

c. The procedures for giving and utilizing incentives as referred to in paragraph (1) shall be regulated by a Government Regulation

In Article 3 Paragraph 2 letter e Government Regulation Number 69 of 2010 concerning procedures for giving and utilizing incentives, it reads: other parties who help government agencies collect taxes and levies.

Further according to the Notary Arung Widya, SH.MKn, said that in Article 3 Paragraph 2 letter e it is stated above that the other party referred to is a Notary in collecting taxes.Based on the results of this study, through interviews with some of the sources mentioned above, it shows that the implementation of the imposition of Added Tax Value (ATV) on Notary Services cannot be implemented in accordance with the provisions of laws and regulations. This happens because of several things as follows:

a. There are still differences of views among tax practitioners, both from the Tax Consultant, Notary, and from the Tax Office itself regarding the basis for tax imposition.

b. The tax office will find it difficult to determine the amount of tax obligation that must be borne by the Notary because there is no specified service contract value between the services provider to the Notary. In practice, the amount of notary services varies for each notary or each region.

c. There is no Notary who voluntarily establishes himself as a Taxable Entrepreneur.

d. Notaries generally refuse to collect ATV on services provided because there is no incentive or collection fee determined by the Regional Government.

3.3. Solution to the constraints of the Implementation of Added Tax Value (PPN) Imposition on Notary Services/Land Deed Making Officials (PPAT) Based on the Added Tax Value (ATV) Law

Notary is a certain position that carries out the profession in legal services to the community. The problem that arises at this time is the inconsistency in the mention of entrepreneurs to notaries as public officials to be given the title "Entrepreneur" in

${ }^{10}$ Interview with Arung Widya, SH.MKn, Notary in Kendari, on 2 February 2020 
connection with their inauguration as a Taxable Entrepreneur (PKP) which basically can be understood and understood, especially if it is related to their position/status of work as a public official. . However, for the Directorate General of Taxes, on the other hand, there arises a juridical difficulty to use other terms, other than PKP terms/designations for confirmed Notaries, because the Law on Added Tax Value only recognizes one title for the subject of Added Tax Value both in the position of a trader/industrialist/importer/manufacturer or a Service Entrepreneur, namely both referred to as a Taxable Entrepreneur (PKP). In addition, the term PKP is already a standard term in the Law on Added Tax Value ${ }^{11}$.

In connection with services performed by Notaries and PPAT, several things need to be considered for future harmonization of legislation so that it can be implemented. First, signing an authentic deed that is not done before a notary public may result in the Notary being unable to qualify as an entrepreneur subject to ATV because the notary is not a profession but an official, besides that the service provider to the notary is not a consumer, thus services in the notary sector are not included in the type. services subject to ATV. Second, notary services are not included in business activities, because notaries are officials who carry out their positions in accordance with the law. Notaries are not entrepreneurs and the public as users of their services are not consumers, so that the services provided are unlike any other profession. Thus, notary services are not subject to ATV. Third, the forward arrangement that notary services are included in certain service categories that are not subject to ATV. This is because the services provided by Notaries as General Officials/are not the same as legal services provided by practitioners in other fields of law, the Notary's services should be included in services that are not subject to Added Tax Value as is also provided for several other types of services.

In this regard, in the future we need a harmonization of laws and regulations regarding the collection of ATV on Notary services. Need to confirm the position of the Notary as Entrepreneur or as Officer. Based on the results of the study, the authors argue that the notary position should be exempted from the ATV object. This is in accordance with the results of previous studies showing that there are difficulties in implementing the provisions on tax imposition for notary services. Notary services are not included in business activities, because notaries are not entrepreneurs and their clients are not consumers. In the Law on the Position of Notary in Article 1 paragraph 1 the definition of Notary is as a General Officer, while in the Law on Added Tax Value in article 3A paragraph 1 and Regulation of the Minister of Finance Number 197/PMK. 03/2013 classifies Notaries/Land Deed Making Officials (PPAT) as entrepreneurs, this can lead to differences in interpretation by the Notary/Land Deed Making Official (PPAT). Notaries should cooperate with related government agencies such as the Office of the Director General of Taxes, KPP and accounting firms in conducting integrated and

\footnotetext{
${ }^{11}$ Ferdiyanti, M. Indah Verena., Purnawan, Amin., \& Soegiyanto. (2019). Setting the Effectiveness of Law Position and Code Notary to the Quality of Performance. JURNAL AKTA: Vol. 6, No. 4, 797-804. Retrieved from http://jurnal.unissula.ac.id/index.php/akta/article/view/7887
} 
routine guidance and socialization regarding Notary taxation, Notary registration and bookkeeping.

If the Notary Services is still positioned as a Taxable Entrepreneur, then several things related to regulations that need to be harmonized and renewed are:

a. The need for affirmation in every regulation regarding the position of a Notary as a Taxable Entrepreneur.

b. It is necessary to determine the rate for notary services for each service provided so that the government will find it easier to determine the amount of tax that must be charged to the Notary Public or PPAT.

c. It is necessary to regulate the related levies for notary services so that notaries in providing services have legal responsibility because they get wages from the state.

\section{Closing}

The implementation of the imposition of Added Tax Value (PPN) on the services of notaries/land deed maker officials (PPAT) based on the Added Tax Value Law has not yet been implemented in accordance with applicable regulations. This is because there are still differences in views regarding the basis for tax imposition, the absence of uniformity in the value of notary services so that it makes it difficult to calculate ATV charges, the absence of a Notary who voluntarily establishes himself as a Taxable Entrepreneur, there is no incentive or collection fee for Notaries/PPAT. And legal services provided by notaries are public legal services that are very much needed by the general public, in order to achieve legal certainty and justice, which among others is by making agreements into authentic deeds that must be made before a notary, so for legal services like this is one of the services that are needed by the public at large, and therefore it is better if the services provided by a notary are not included as services subject to Added Tax Value.

\section{References}

\section{Journal:}

Ferdiyanti, M. Indah Verena., Purnawan, Amin., \& Soegiyanto. (2019). Setting the Effectiveness of Law Position and Code Notary to the Quality of Performance. JURNAL AKTA: Vol. 6, No. 4, 797-804. Retrieved from http://jurnal.unissula.ac.id/index.php/akta/article/view/7887

Books:

[1] Wirawan, B. Ilyas and Richad Buston. (2013). Hukum Pajak. Jakarta: Bina Kata

[2] Judisenno, Rimsky K. (2002). Pajak Dan Strategi Bisnis (Suatu Tinjauan Tentang Kepastian Hukum Dan Penerapan Akuntansi Di Indonesia. Jakarta: Gramedia Pustaka Umum 
[3] Sukardji, Untung. (2015). Pokok-pokok Pajak Pertambahan Nilai Indonesia edisi revisi 2015. Jakarta: Raja Grafindo

[4] Dr. Ngadino. Sh. Sp.N. MH. (2019). Tugas Dan Tanggung Jawab Jabatan Notaris Di Indonesia. Semarang: Univ. PGRI Semarang Press

[5] Dr. Ngadino. SH. Sp.N. MH. (2019). Ketentuan Umum Tata Cara Pembuatan dan Pengisian Akta PPAT. Semarang: Univ. PGRI Semarang Press

\section{Regulations:}

[1] Act No. 2 of 2014 concerning Amendments to Act No. 30 of 2004 concerning the Position of Notary Public

[2] Act No. 42 of 2009 concerning the third amendment to Act No. 8 of 1983 concerning Added Tax Value and Services and Sales Tax on Goods and Services and Sales Tax on Luxury Goods

[3] Government Regulation Number 37 of 1998 concerning PPAT Position

Internet:

https://www.pajak.go.id/id/artikel/kemandiran-yang-menginspirasi, accessed on 16 October 2019

Interviews:

[1] Interview with Arum, SE., Kendari Pratama Tax Officer, on 12 January 2020

[2] Interview with Rima Anggraini, SH.MKn., Notary in Kendari on 12 January 2020

[3] Interview with Lutfi, Notary in Kendari, on 14 January, 2020

Interview with Arung Widya, SH.MKn, Notary in Kendari, on 2 February 2020 